\title{
TRANSFER THE FUNCTION OF FORECASTING TO 3PL ENTERPRISE IN DISTRIBUTION NETWORK - THEORETICAL CONSIDERATIONS
}

\author{
Mariusz KMIECIK \\ Politechnika Śląska, Wydział Organizacji i Zarządzania, Zabrze; mariusz.kmiecik@polsl.pl; \\ ORCID: 0000-0003-2015-1132
}

\begin{abstract}
Purpose: The main goal of article focuses on identification the main research directions for transferring the function of centralised demand forecasting to 3PL enterprise. To meet this goal the concepts connected with central demand forecasting in distribution network was considered and it was taking into account the meaning of demand management and forecasting in logistics. There were also distinguished the main stages which could include the attributes of central forecasting enterprise.

Design/methodology/approach: Paper includes literature analysis connected with centralised forecasting and specification of determinants which could be the main reference point in finding the enterprise able to get the function of centralised forecasting.

Findings: According to literature review determinants of distribution network configuration in the centralised forecasting is showed and also there is showed a possibility of transfer the function of centralised forecasting to logistic operator.

Originality/value Paper shows determinants of distribution network configuration in the conditions of centralised forecasting and takes into account possibility of transfer this function to logistic operator.
\end{abstract}

Keywords: centralised demand forecasting, distribution network, logistic operator.

\section{Introduction}

Efficient providing the goods and services to the customers was always the main purpose of cooperation in distribution networks. Firstly, enterprises didn't have a strong need to tightening to cooperation with their co-operators and relations were limited only to simple transactions. Nowadays enterprises which cooperated in distribution channels are striving for close activities integrations to satisfy customer needs. Increasing customer requirements implicate the necessity of reconfigurations of the whole supply chains and, in them, the necessity of distribution networks configurations too. Striving for meeting the customer 
needs implicate the necessity of creation the fixable and dynamic market systems which are able to ensure efficient information and materials flows. Suitable distribution network configuration gives opportunities to quick reaction for customer needs and demand changes.

One of the factors, which has influence on distribution network shape are demand's fluctuations for products which are the subject of material flows. Ability to react to these fluctuations is described as the one of the fundaments of creation the competitive advantage. To keeping mentioned reaction ability, enterprises are creating the sales forecasts. This kind of forecasts are defined as: predicting the future facts and occurrences of particular goods. The basis to designate them are usually time series which illustrate the selling history. Forecasts are creating the processes and operations connected with decisions about quantities of ordered goods, materials, manufacturing goods and so on. It could improve the planning processes in whole areas of logistics and in conjunction with it the idea of forecasting in logistics is one of the key problems which require analysis in the conditions of contemporary enterprises.

Next, currently important form of distribution network configuration, except mentioned cooperation and creation of streams based on demand management system is the increasing meaning of logistics operators. Nowadays, logistics services market is the most growing in the Europe and even in the World - this trend is also visible in Poland. Logistics operators are looking to their business models favouritism possibilities in terms of competitors. It is indicated by fact that the shares of logistics operators in the market continually increasing and specialisation of offered services are wider.

The purpose of the following paper is an identification of main research directions connected with transferring the function of centralised forecasting to logistic operator. Completing the goal will allow to narrow the searching for central forecasting enterprise attributes only for the main areas. In the future, researches will allow also to compare specified features with attributes of logistic operators and answer the question that the logistics operators are able to take over the function of centralised forecasting entity in distribution network. Research methodology focuses on literature review. Literature review consists of consideration about logistics operators, distribution networks and elements of distribution network configuration which could have influence of transferring the central forecasting function to 3PL enterprise.

\section{Logistic operators in distribution networks}

Outsourcing means to use an external source (Gołembska, 2010). Striving for based activities concentration caused that additional services started to be commissioned to specialised logistic operators (Bendkowski, Kramarz, 2006). Logistic processes which are entrusted to specialised service provides is described as outsourcing or contract logistic 
(Murphy, Wood, 2011). The idea of service transferring is about riddance of some logistic functions. Outsourcing had origins in transportation processes, where the enterprises have started to notice that keeping and exploitation own vehicles fleet is expensive undertaking. Nowadays, the most common direction of outsourcing are activities connected with: IT, HR, distribution, logistic and finances or accountancy (Bendkowski, 2008).

Outsourcing could be used in the particular stages of implementation of conceptions like reengineering or lean management. Especially Particularly important issue is also a strategic outsourcing, which focuses on close cooperation between entities. Often, with reference to strategic outsourcing, are used forms such as (Gołembska, 2010): co-outsourcing entity transfer their qualified workers to execution a particular tasks, service outsourcing using a skills and qualifies of chosen entity which allows to focus on key activities and create a competitive advantage and last form - shares in benefits - creation a long term relationship with common risk borne.

Logistics operators are considered by some authors to be able to have a function of leader in supply chains (Kawa, 2011). They are able to handle with decisions connected with management and other issues like in ex. continuous improvement and distribution networks and supply chains reconfiguration. Logistics operators, despite relative long existence, are one of the trends in logistics. Third-party logistics entities (3PL) are one of the most common logistic operators in the market. They provide a variety of services. The most popular services are: external transportation, negotiations and confirmations of transportation agreements, warehousing and goods consolidations (Murphy, Wood, 2011). Some 3PL enterprises are expanding their activities with complementary services (like: products assembling or installing). Use a 3PL decision is often justified by strategic issues, where enterprise concludes that one or more activity elements should be change.

Using services offered by 3PL belongs to common tendency of logistic outsourcing. It is estimated that 3PL, regardless the type of outsourcing, is able to reduce the client expenses by $20-30 \%$ (Barcik, Kubański, 2011). It is possible by for ex. appropriate warehouse management or logistic handling of reverse material streams. Next benefit of using 3PL could be also capacity and efficiency improvement, however it must be taken into considerations that cooperation with 3PL could easily fail. One of the most common and most important barrier during implementation and cooperation with 3PL are unreal expectations of enterprises using 3PL services (Murphy, Wood, 2011). Next cause is lack of flexibility of both sides for unexpected activities, which are deviated from fixed factors and no treatment of service provider in partnership way. As was mentioned, 3PL entities dominates on market. It could be distinguished 3 types of such entities (Żebrucki, 2012): entities which use fixed assets, and which based their activity on owned or rented material resources, net entities developed by global communication networks and transportation networks (their activity based on information services) and entities which are creating their market position based on skills - 
they don't have logistic infrastructure and they activities based on knowledge. Last entities type is close to 4PL (logistics operators), but they are less complex.

Increasing meaning of logistic operators is one of whole supply chains and distribution centres development determinant (Antonowicz, 2016). Customers are looking for more advanced services which are offered by operators. One of such a service could be a function of centralised forecasting.

\section{Conception of centralised forecasting}

\subsection{The meaning of forecasting in logistic}

Forecasts are considered as one of risk category in material flows (Kramarz, 2013). Risk factors connected with forecasting are: imprecision, seasonality, product differentiation, short product life cycle, not enough customer data base and information deviation. Demand ${ }^{1}$ fluctuations could imply supply management problems (Ciesielski, 2008) and create tendency to keeping excessive stocks. In the case of transportation processes demand forecasts have indirect impact. Entity could make plans of required fleet quantity, human resources and also create a schedule adjusted to transport of forecasted goods. The idea of forecast could be described by using 4 features (Zeliaś, 1997):

- forecast based on science achievements,

- forecast is a statement which applies to definite future,

- forecast is an empirically verifiable statement,

- forecast is not a firm statement, but an acceptable statement.

Forecasting has special importance as one of the means using in enterprise management processes, because wrong prediction of future trends could imply devastating consequences for whole company. Request for forecasts in enterprise is formed by 2 basic reasons (Dittmann, 2000): lack of certainty connected with the future and delayed between moments of decision making and their effects. Main forecasts functions are presented in table 1.

Using flexible and precise forecasting procedures gives possibilities to gain good results even in capricious markets where ordering practice of middleman distorts demand of ended participants (Bendkowski et al., 2010). During considerations about forecasting meaning in companies' activity the special attention should be paid to wrong created forecasts. Demand revaluation could cause in ex. by: high costs of excessive stocks and high marketing costs to get rid of them. Underestimation, on the other hand, could cause in ex. by: lost sales, lost reputation and underestimated level of sales tasks (Hentschel, 2015).

\footnotetext{
${ }^{1}$ Demand in this paper is understanding as demand of products which flows through distribution network.
} 
Table 1.

Chosen forecast functions

\begin{tabular}{|c|l|}
\hline Function & \multicolumn{1}{c|}{ Characteristic } \\
\hline Dissecting & $\begin{array}{l}\text { Recognized as the most important function. Focuses on rational decision processes } \\
\text { supporting. It creates basis to making a real decision. }\end{array}$ \\
\hline Activating & $\begin{array}{l}\text { Focuses on stimulation of activities which are forecasting friendly. It announces } \\
\text { happenings which are favorable or not. }\end{array}$ \\
\hline Information & $\begin{array}{l}\text { It involves reducing the fear and uncertainty associated with events that will take place in } \\
\text { the future. }\end{array}$ \\
\hline
\end{tabular}

Source: own elaboration based on (Iwaszczuk et al., 2013).

\subsection{Centralised forecasting}

In whole World expansion and reconfiguration of global corporation distribution structures is observed (Rutkowski, 2015) and in this - activities such as centralisation and decentralisation. In the market there is no one ideal pattern of organisational structure, which could meet the requirements connected with demand management. However, one of the most important issue, which could meet mentioned requirements is efficient data transfer between particular participants of network. It is possible by using widely available data base (Kawa, 2009). In this base are gathered and saved information, which have been generated in different enterprises belonging to the network. Among features, which appoint adjusting level of entity organisational structure to requirements connected with demand management it could be distinguish for ex. level of work progress standardisation, hierarchical relations and power centralisation. Literature also emphasis on that during forecasting and demand planning could be taken 2 main decisions (Aertsen et al., 2016). First is connected with reporting line of demand planning entity (set to operational and supply chain management or sales and marketing). Second is connected with centralisation level (centralised or decentralised).

Necessity of demand management incorporation in network activity is strictly connected with necessity of centralisation (Szozda, Świerczek, 2016). It could be distinguished 2 basic activities centralisation possibilities (Pfhol, 1998): concentrating tasks in an independent organisational unit which based on the principle of cross-sectional function and second which is concentrating tasks in independent organisational unit, which exists next to other units in this issue it is necessary to grouping a function of demand management. One of the main features of centralisation is the consolidation of activities connected with demand management and grouping them in separate functional area (Szozda, Świerczek, 2016). Level of centralisation advance shows in which level decisions are taking, who has the power and influence skills and who's get a proper permission. Centralisation is also perceived as concentration of activities connected with planning in one, separate and formalised unit (Brito, 2016). 
The system of central forecasts gives first the information of forecasts for supply chain. Buyers and suppliers act in next order (they are called as second movers), where after gathered from central system information analysis they decided to make moves according or against of set plan (Kristiano et al., 2012).

Usage of centralised forecasting leads to get different results depending on surrounding type where is implemented. The results of central forecasts could be (Brito, 2016; Thute, 2003):

- greater level of activities controls and harmonization,

- better entities in networks and chains adjusting,

- improving a flows efficiency,

- lower network costs,

- transparent and precise forecasts,

- bullwhip effect reduction.

Additionally, centralised forecasting could significantly lower the fluctuations of orders quantity. It could be also possible a lowering a quantity and eliminating significant fluctuation in orders from particular network nodes (figure 1).

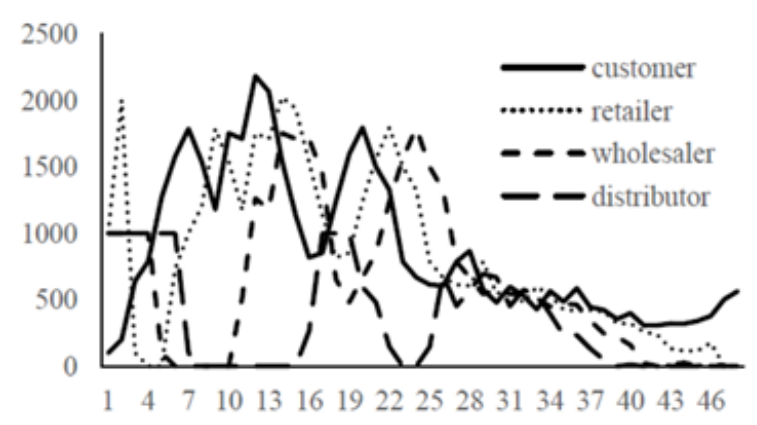

Decentralized forecasting

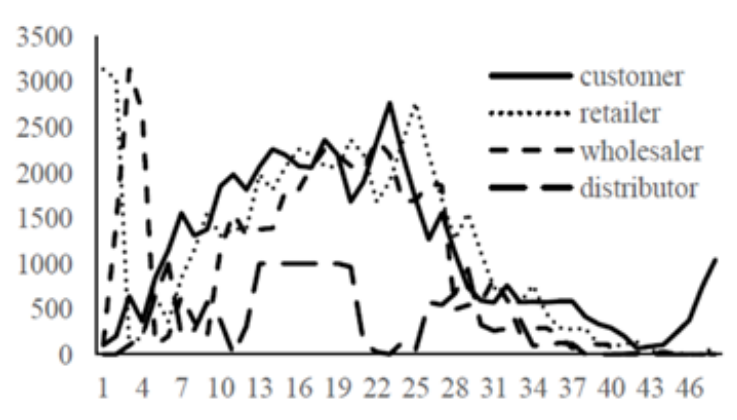

Centralized forecasting

Figure 1. Quantity of orders from particular nodes in the system of decentralised and centralised forecasts Source: (Abad, 2014).

In centralized version of forecasting the demand levels of particular nodes in distribution network is similar. In decentralized version - these levels are extremely different. It causes a lot of disruption in whole network. Strategies used by central enterprise in distribution network have influence on adaptability of whole network (Kramarz, 2015). For that reason, showing the features of central distribution network node, which decided about choosing new nodes and which controls material flows is an important issue. 


\section{The issue of transferring the central forecasting function to $3 \mathrm{PL}$}

Transferring the central forecasting function to logistic operator could bring a plenty of benefits for whole distribution network. Among mentioned benefit it could be distinguished factors like:

- processing the forecasting data in plans and fast reaction by adjusting logistics processes,

- developing the operator-recipient cooperation which could allow to better usage of operator's potential and higher services recipients and even ended customer satisfaction level,

- faster reaction to demand changes and faster adjusting logistics activities,

- better products flow control in the network,

- possibility of additional improvements implementation to particular processes in depended of demand kind,

- extension the range of offered services.

However, before the try of transferring mentioned function to 3PL it is necessity of consideration of few barriers. These barriers are connected in ex. with necessity of changes in agreements, in structures and relationships in distribution network to adjust it to operating the centralised forecasting, implement new management conceptions and specification the attributes which could be at the same time the attributes of central forecasting enterprise and compare them whit possibilities and skills of logistic operator.

The set of main areas of enterprise activities connected with central forecasts allows to narrowing the research about searching for central forecasting enterprise attributes. The set of main elements, which should be considered during the examination of implementation and transferring the central forecasting function to $3 \mathrm{PL}$ issue is showed in figure 2 .

To elements mentioned in figure 2 could be also added areas like: localisation of nodes, which could have influence on process efficiency, system and information determinants and the kind of products demand which shapes the processes in distribution network. Referring to main areas where the considerations about transferring the function of centralised forecasting should focus on it is needed to interpret concepts connected with it.

Configuration of distribution network should focuses on the tasks connected with handling in the space, which includes construction in them coordinate or functional structural systems (Frankowska, 2016) or in more detailed point of view - with structural decisions which determine relationship between nodes, quantities, time and also characterised by enterprises politics in the range of production, distribution, information exchanging and using outsourcing strategies (Kawa, 2009, 2011). 


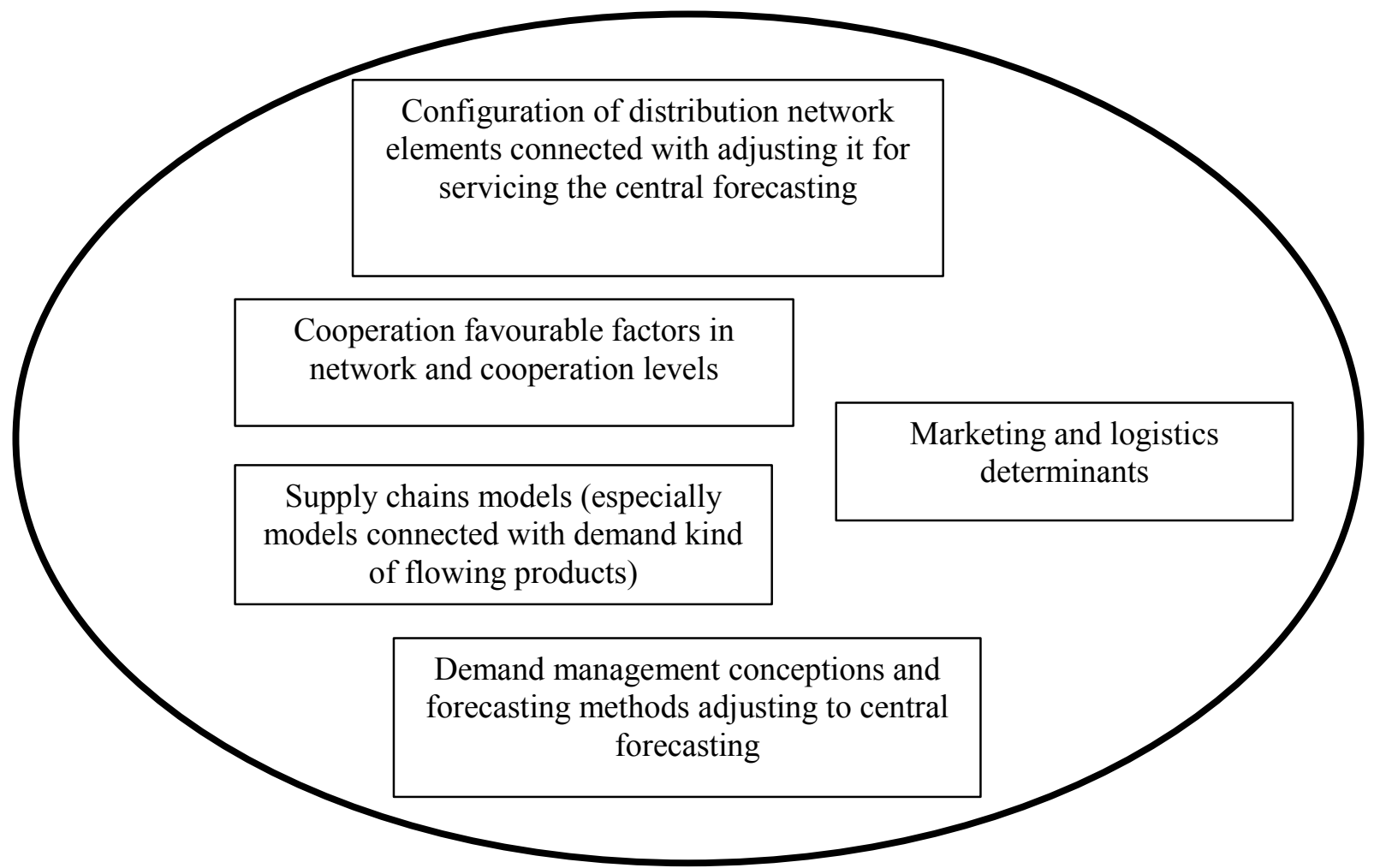

Figure2. Main considerations elements connected with transferring the function of central forecasting to 3PL issue. source: own elaboration.

The issue of coaction and cooperation in literature is interpreted in a lot of ways. According to Polish dictionary PWN cooperation is defined as: activates carried out jointly by some persons, institutions or counties. On the other hand, coaction is defined as one of the noun form from: act together with someone or contribute to something with other participants. One of approach using in Polish literature treats coaction like something more than cooperation. It assumes that cooperation is one of the coaction forms (Czarniawski, 2002; Żebrucki, 2012; Polak, 2016). Cooperation is treated as something positive. With reference to network, cooperation is understanding as: formal or informal relations between manufacturers, suppliers, customers and other business partners, which are established and tightened in the aim of capacity improvement (Murphy, Wood, 2011). One of main cooperated network challenges is keeping stocks in proper level in whole network - not only in one node. Coaction could be perceived as repeatable and relative permanently connections, which causes a different form of cooperation (Jagoda, Lichtarski, 2002). The coaction base is a mutual trust, loyalty and acting in the interests of all parties. The basic elements of coaction are: involvement, exchange and reciprocity (Czakon, 2005; Lipka, 2004; Polak, 2016).

The supply chains models are considered in few different perspectives. First classification could be grouping the supply chains to nodes quantity and connections between them according to that it could be distinguish directly supply chains (consisting of supplier, organisation and customer), extended supply chains (extended by subcontractors) and network supply chains, which take into account in ex. logistics operators, investors and market 
researches. The supply chain model could be also determined from localisation of material decoupling point (MDP). For example: in assembly to order model (ATO) distribution enterprises could realise the tasks of postponed production. Network relations are complex and intensive. In make to order model (MTO) distribution channels are shortened, so distribution role is limited (Kramarz, 2015). In engineering to order model (ETO) supply chain configuration is changed, networks are created in the suppliers' level, and in distribution areas are created a directly channels.

Next important element are conceptions connected with demand management, which allows to creation a coordinated demand information flows (Murphy, Wood, 2011). Among elements including in demand management it could be distinguish (Szozda, Świerczek, 2016): demand planning, demand information communication, influence to demand and demand prioritisation. These elements should be compared with centralised forecasting conditions. In demand management important role have forecasting stage. Demand forecasts could be created by using in ex. moving averages, exponential smoothing, autoregression or by creating an artificial neural networks.

Next are marketing and logistic determinants. It should be considered what is the influence of acquiring way, customisation requirements, acquiring place, products feature and the level of differentiation and market segmentation on the features of central forecasting enterprise (Kramarz, 2014, 2009). These areas, what was mentioned, should gives a base to searching in them a attributes of central forecasting enterprise in distribution network.

Depth analysis of showed areas could give answers to fallowing questions:

- what relationship skills should have a 3PL entity and what is the level of nodes integration which could him reach in the aim of serving the centralised forecasting?

- Is the level of possible demand information gaining level using existing IT systems and management methods will be enough to service centralised forecasting?

- Does the 3PL will be able to convince previous service recipients to transfer sensitive information?

- Does the 3PL will have proper forecast knowledge, data analysis skills and proper inference process without expert basis?

The answers to these questions and further problem analysis allows to state that logistic operator is able to take over the function of central forecasting in distribution network. 


\section{Summary}

Article showed the conception connected with outsourcing, forecasting meaning in logistic and centralised forecasting and showed the necessity of further researches in these areas. Fallowing paper pointed also some guidelines about main areas which could allow to implementation and servicing the centralised forecasting, so the paper purpose was fulfilled.

Mentioned areas mainly concerned the way of distribution network configuration, creation of proper cooperation level and choosing the proper demand management and forecasting methods. These attributes after identification will be compare with 3PL attributes. The guidelines about necessary attributes could in the future gives the basis to creation the model of 3PL enterprise which will be able to making a central forecast to whole distribution network. These model is an interesting area of future research connected with centralisation in distribution network and transferring the function of forecasting to 3PL enterprise. It is necessary to confront whole attributes of 3PL, attributes of central node and determinants of distribution network configuration. Autor suppose that it is possible to create the model of distribution network with $3 \mathrm{PL}$ in the central node which be able to create a high accuracy forecasts.

\section{References}

1. Abad, A.G. (2014). Modelling of centralized demand in supply chains using integer programming, Twelfth LACCEI Latin American and Caribbean Conference for Engineering and Technology (LACCEI'2014) "Excellence in Engineering To Enhance a Country's Productivity", Ecuador.

2. Aertsen, F., Blanc, I.I., Rongen, J., Wouwe, L. (2016). Building a competitive demand planning organization, An Eyeon White Paper, 4-16.

3. Antonowicz, M. (2016). Wyzwania logistyczne firm - elastyczne łańcuchy dostaw. Zeszyty Naukowe Uniwersytetu Ekonomicznego w Katowicach, 255, 215-229.

4. Barcik, R., Kubański, M. (2011). Współczesne trendy w zarządzaniu łańcuchem dostaw. Logistyka, 2, 55-66.

5. Bendkowski, J. (2008). Wybrane elementy zarzadzania logistyka w przedsiębiorstwie. Gliwice: Wyd. Politechniki Śląskiej.

6. Bendkowski, J., Kramarz, M. (2006). Logistyka stosowana. Metody, techniki i analizy. Gliwice: Wyd. Politechniki Śląskiej.

7. Brito, B. (2016). Centralization of supply chain management operations: the case of Unilever Ultralogistik. Universidade do Porto, Porto. 
8. Ciesielski, M. (2009). Instrumenty zarządzania łańcuchami dostaw. Warszawa: PWE.

9. Czakon, W. (2005). Istota relacji sieciowych przedsiębiorstwa, Przegląd Organizacji, 9, 10-13.

10. Czarniawski, H. (2002). Współdziałanie potrzeba czasu. Lublin: Norbertinum.

11. Dittmann, P. (2000). Metody prognozowania sprzedaży w przedsiębiorstwie. Wrocław: Wydawnictwo Akademii Ekonomicznej im. Oskara Langego.

12. Frankowska, M. (2016). Konfiguracja przestrzenna łańcuchów dostaw - uwarunkowania logistyczne i konkurencyjne, PTiL, 3, 39-51.

13. Gołembska, E. (2010). Kompendium wiedzy o logistyce. Warszawa: PWE.

14. Hentschel, B., Cyplik, P., Hadaś, Ł., Domański, R., Adamczak, M., Kupczyk, M., Pruska, Ż. (2015). Wieloaspektowe uwarunkowania integracji łańcucha dostaw typu forward i backward. Poznań: Wyższa Szkoła Logistyki.

15. Iwaszczuk, M., Drygaś, P., Pusz, P., Pusz, R. (2013). Prognozowanie gospodarcze. Rzeszów: Wyd. Wo.

16. Jagoda, H., Lichtarski, J. (2002). Kilka uwag o stanie i tendencjach w zakresie współdziałania gospodarczego przedsiębiorstw. In: J. Skalik (ed.), Zmiana warunkiem sukcesu. Integracja, globalizacja, regionalizacja - wyzwania dla przedsiębiorstw. Wrocław: Wydawnictwo Akademii Ekonomicznej.

17. Kawa, A. (2009). Zastosowanie technologii agentowej w konfigurowaniu łańcucha dostaw. Uniwersytet Ekonomiczny w Poznaniu, Wydział Zarządzania.

18. Kawa, A. (2011). Konfigurowanie tańcucha dostaw. Teoria, instrumenty i technologie. Poznań: wyd. Uniwersytetu Ekonomicznego.

19. Kramarz, M. (2009). Analiza otoczenia łańcucha dostaw jako etap konfiguracji złożonego systemu logistycznego na przykładzie branży farmaceutycznej. LogForum, 5, 1-9.

20. Kramarz, M. (2014). Elementy logistyczne obstugi klienta w sieciach dystrybucji. Pomiar, ocena, strategie. Warszawa: Difin.

21. Kramarz, M. (2015). Klastry i sieci dystrybucji we wzmacnianiu odporności i adaptacyjności łańcucha dostaw. Zeszyty Naukowe Politechniki Ślaskiej, 78, 179-191.

22. Kramarz, W. (2013). Modelowanie przepływów materiałowych w sieciowych łańcuchach dostaw. Odporność sieciowego łańcucha dostaw wyrobów hutniczych. Warszawa: Difin.

23. Kristianto, Y., Helo, P., Jiao, J., Sandhu, M. (2012). Adaptive fuzzy vendor managed inventory control fo mitigating the Bullwhip effect in supply chains. European Journal of Operational Research, 216, 346-355.

24. Lipka, A. (2004). Współdziałanie. Zmierzch rywalizacji pracowników. Warszawa: Difin.

25. Murphy, P.R., Wood, D.F. (2011). Nowoczesna logistyka. Gliwice: Helion.

26. Pfhol, H.Ch. (1998). Systemy logistyczne. Poznań: Instytut Logistyki i Magazynowania.

27. Polak, J. (2016). Współpraca i współdziałanie międzyorganizacyjne w telekomunikacji mobilnej. Zeszyty Naukowe Uniwersytetu Ekonomicznego w Katowicach, 299, 284-292. 
28. Rutkowski， K. (2015). Rekonfiguracja międzynarodowych łańcuchów dostaw jako narzędzie zapobiegania zagrożeniom kryzysowym - szansa dla Polski. Prace Naukowe Uniwersytetu Ekonomicznego we Wrocławiu, 382, 92-104.

29. Słownik Języka Polskiego PWN, https://sjp.pwn.pl/.

30. Szozda, N., Świerczek, A. (2016). Zarządzanie popytem na produkty w łańcuchu dostaw. Warszawa: PWE.

31. Thute, A.A. (2003). Supply chain optimization of carton manufacturing and procurement process. Florida: Florida State University.

32. Żebrucki, Z. (2012). Badania form partnerstwa logistycznego między przedsiębiorstwami. Gliwice: Wyd. Politechniki Śląskiej.

33. Zeliaś, A. (1997). Teoria prognozy. Warszawa: PWE. 